\title{
SUPPRESSION OF DAMAGING EFFECTS OF Callosobruchus maculatus (F.) (Coleoptera: Chrysomelidae) BY PLANT POWDERS
}

\author{
*Yusuf, S. Y., Musa, A. K., Adebayo, A. G. and Lawal, M. T. \\ Department of Crop Protection, \\ University of llorin, P. M. B. 1515, llorin, Nigeria. \\ *Corresponding Author: yusuf.sy@unilorin.edu.ng; (+23470349841820)
}

\begin{abstract}
Powders prepared from plant species available in Nigeria are reported to possess ovicidal, larvicidal, pesticidal, antifeedant and repellent properties against various insect pests and are regarded as environmentally compatible pesticides. This study evaluated the action of Azadirachta indica A. Juss, Hyptis suaveolens Poit. Piper guineense Thonn. \& Schum and Cymbopogon citratus Gaern against the damaging effects of Callosobruchus maculatus (F.) in stored cowpea. The experiment was carried out at temperature of $30 \pm 1{ }^{\circ} \mathrm{C}$ and relative humidity of $72 \pm 3 \%$. The plant powders were compared at the rate of $2.5 \mathrm{~g}$ per $50 \mathrm{~g}$ cowpea seeds including the untreated control. The experiment was laid out in a completely randomized design with three replications. The results showed that all the botanicals gave protection to the stored cowpea seeds and significantly $(p<0.05)$ reduced mean adult emergence and seed weight loss $(3.75-4.06 \%)$ caused by C. maculatus when compared with the untreated control $(6.07 \%)$. The number of emerged adults from untreated seeds progressively increased with time of exposure compared to the treated seeds. The increasing order of effectiveness of the botanicals in terms of their insecticidal activities against $C$. maculatus was $P$. guineense, $C$. citratus, $H$. suaveolens, and $A$. indica. The study, therefore, shows that the botanicals could serve as protectants against C. maculatus in stored cowpea seeds.
\end{abstract}

Keywords: Botanicals, Callosobruchus maculatus, Cowpea, Damage, Mortality, Protectants 


\section{INTRODUCTION}

Cowpea (Vigna unguiculata L. Walp) originated from Africa where a large number of primitive cultivars and semi-wild forms are found (Kwaifa et al., 2012). It is grown for food and animal feed in the semi-arid tropics of Africa, Asia, Europe, Central and South America (Asante et al., 2001). The crop is an important edible grain legume being very rich in protein required by man and livestock (Akinkurolere et al., 2006). Cowpea, therefore, nutritionally complements staple low protein cereals and tuber crops and provides income for farmers and traders (Lanyintuo et al., 2003).

In addition to the high protein content of cowpea, it also has high iron content but is low in fats. Cowpea has also been valuable in nitrogen fixation through its root nodules, and it grows well in poor soils with more than $85 \%$ sand and with less than $0.2 \%$ organic matter and low levels of phosphorus (Singh et al., 2003).

Seed beetle, Callosobruchus maculatus ( $F$.) is unarguably a major insect pest militating against food availability and security (Adedire, 2008). Storage of cowpea seeds over long periods, especially at small holder levels, is limited by bean beetle infestation. Huge losses of between 20 and $50 \%$ have been reported on stored cowpea due to attack by bean beetle, $C$. maculatus and sometimes the loss could be complete accounting for 100\% loss (Udo and Harry, 2013). Bean beetle also attacks chickpeas (Cicer sp.), lentils (Lens sp.), garden peas (Pisum sp.) and mung beans (Vigna sp.) with distinctive damage. Their damage causes loss of weight, nutritional value and viability of stored seeds particularly caused by larvae. Adult female $C$. maculatus lays half its total eggs in the first two days after copulation (Uddin II and Sanusi, 2013).

The major problems associated with the use of synthetic pesticides against the pest include the dangers to the user, exorbitant costs, pesticide resistance and food residue. Improper application of synthetic pesticides poses a threat to man and the environment, particularly among rural farmers in Africa (Ofuya, 2003). These setbacks have made the quest for alternative approaches to the pest control including plant products, very expedient (Lale, 2002).

Currently, global research efforts now support the development of plant products with proven crop protection potentials (Aliyu et al., 2011). Rahman and Talukder (2006) reported that grains mixed with leaf, seed powder, or plant extracts reduced oviposition, inhibited damage and suppressed adult emergence of $C$. maculatus.

In another investigation, plant powders applied at $2 \%$ of the weight of stored beans effectively controlled cowpea seed beetle in storage (Lale, 2002). In the tropics, some of the plant species that have been screened for insecticidal properties include Azadirachta indica A. Juss, Piper 
guineense Schum. \& Thonn. and Dennettia tripetala G. Baker (Lale, 2006). The inclusion of plant products in pest management may offer a reliable and environmentally safe alternative to synthetic insecticides. This study therefore determined the efficacy of $A$. indica, Hyptis suaveolens Poit., P. guineense and Cymbopogon citratus Gaern against bean beetle, $C$. maculatus ( $F$.) in stored cowpea.

\section{MATERIALS AND METHODS}

\section{Experimental Study}

The research was carried out at the Biotechnology Laboratory, University of llorin, Ilorin, Nigeria. The cowpea (variety Beluko) used for this experiment was purchased from an agro-allied shop, Amilegbe, llorin.

\section{Insect Culture}

The initial stock culture of $C$. maculatus was maintained in the laboratory of the Department of Crop Protection, University of llorin, Ilorin, Nigeria. Sub-cultures of the insect were prepared from 25 pairs of the adult insect randomly picked from the stock culture. The insects were raised on dry susceptible white cowpea seeds in plastic containers covered with muslin cloth to allow aeration and prevent insect escape. The culture was maintained under prevailing temperature of $30 \pm 1^{\circ} \mathrm{C}$ and relative humidity of $72 \pm 3 \%$. Freshly emerged adults were used for the study.

\section{Seed Sterilization and Plant Powder Preparation}

The cowpea seeds were sterilized in a freezer compartment of a refrigerator for 14 days to eliminate possible hidden insect infestation (Musa and Lawal, 2016). Four researched plants identified as Azadirachta indica A. Juss. (Ivbijaro, 1989), Piper guineense Thonn. \& Schum. (Musa, 2007), Hyptis suaveolens Poit. (Musa, 2008; 2013), and Cymbopogon citratus Gaern (Dike and Mbah, 1992) were collected from the University of llorin campus and its environs. The leaves were air-dried for three weeks, ground separately and thereafter passed through a sieve to obtain fine powder. The plant powders were kept in air-tight vials prior to use.

\section{Experimental Design}

Azadirachta indica, $P$. guineense, $H$. suaveolens, and $C$. citratus leaf powders were evaluated for their ability to protect cowpea seeds against damage by $C$. maculatus. Each plant powder was applied at $2.5 \mathrm{~g}$ per $50 \mathrm{~g}$ cowpea seeds in separate plastic containers $(7.5 \mathrm{~cm}$ in diameter) with ten $C$. maculatus (1-2 day old) adults introduced into each of the containers. Cowpea seeds 
without plant powder were put into a container and served as untreated control. The containers were covered with muslin cloth to allow aeration and prevent insect escape. The experiment was laid out in a completely randomized design with three replications.

\section{Data Collection}

Data collected included adult beetle mortality, adult beetle emergence, seed weight damaged and seed weight loss. The mortality rates were recorded at 1, 2, 3 and 4 days after infestation (DAl) and then expressed as percentage. The newly emerged adults were from the first day of emergence (29 DAT) to 35 DAT. The damaged seeds (seeds with exit holes) in each sample were determined by weighing. The seed weight loss was computed using the method of Musa and Lawal (2016) as follows:

$W=W_{1}-W_{2}$

where:

$W=$ weight difference

$W_{1}=$ original weight (before infestation)

$\mathrm{W}_{2}=$ final weight (after infestation)

\section{Data Analysis}

Data were subjected to analysis of variance while means separation was carried out using Least Significant Difference at $\mathrm{p}=0.05$ level of significance.

\section{RESULTS}

\section{Effect of Plant Powders on the Mortality of $C$. maculatus Adults}

Table 1 shows that $H$. suaveolens and $C$. citratus leaf powders had insecticidal effects against bean beetle at 1 DAT. At 2 DAT, $H$. suaveolens leaf powder caused significantly $(p<0.05)$ higher mortality $(40.0 \%)$ than $C$. citratus $(20.0 \%)$ and $P$. guineense $(20.0 \%)$ leaf powders against the insect. At 3 DAT, there were significantly $(p<0.05)$ higher mortality of $C$. maculatus adults in seeds treated with $A$. indica $(100.0 \%)$ than $P$. guineense $(20.0 \%)$, H. suaveolens $(60.0 \%)$ and $C$. citratus $(60.0 \%)$. However, $H$. suaveolens leaf powder caused total mortality of $C$. maculatus adults at 4 DAT. On the whole, seeds treated with the leaf powders caused varying rates of mortality compared to no mortality in the untreated control during the study period. 


\section{Effect of Plant Powders on Adult Emergence of $C$. maculatus}

Table 2 shows the emergence of $C$. maculatus adults from cowpea seeds treated with leaf powders of $A$. indica, $P$. guineense, $H$. suaveolens and $C$. citratus from 29 to 35 DAT. Hyptis suaveolens inhibited progeny emergence from 29 to 31 DAT while $C$. citratus inhibited progeny emergence from 29 to 30 DAT. The results for the number of emerged adults indicated a highly significant $(p<0.05)$ difference. From 32 to 34 DAT, $H$. suaveolens recorded the lowest mean numbers of emerged adults ranging from $0.67-10.33$, while the untreated control consistently recorded the highest mean numbers of emerged adults ranging from 10.33 to 70.00 between 29 and 35 DAT. Azadirachta indica and $H$. suaveolens showed significant $(p<0.05)$ difference in the mean numbers of emerged adults compared to the untreated control except at 33 DAT. Hyptis suaveolens, $C$. citratus and $A$. indica were statistically the same in reducing the adult emergence at 35 DAT but the $H$. suaveolens caused significantly lower mean adult emergence compared to C. citratus and $A$. indica at 34 DAT. However, the performance of $H$. suaveolens in reducing adult emergence was significantly better than $A$. indica, $P$. guineense and $C$. citratus at 34 DAT.

\section{Effect of Plant Powders on Cowpea Seed Damage}

Table 3 shows the mean weight of cowpea seeds damaged by $C$. maculatus after being treated with the four different leaf powders. The highest mean weight of seeds damaged by the insect was recorded in $P$. guineense $(4.02 \mathrm{~g})$ while $A$. indica had the lowest mean value $(1.57 \mathrm{~g})$. All other treatments had intermediate values. There were no significant $(p>0.05)$ differences among the mean weight of seeds treated with $A$. indica, $P$. guineense, $H$. suaveolens, $C$. citratus and the untreated control. The mean weight of undamaged cowpea seeds with different leaf powders was recorded to be the highest mean value in $A$. indica (46.55) and lowest mean value in $P$. guineenses (43.95) while other treatments had intermediate values. There were no significant $(p>0.05)$ differences in the mean weights of undamaged cowpea seeds for all the treatments including the untreated control.

\section{Effect of Plant Powders on Seed Weight Loss}

Table 4 shows the mean seed weight loss caused by the four different leaf powders. There were no significant $(p>0.05)$ differences among the mean weight loss of cowpea seeds treated with $A$. indica, $P$. guineense, $H$. suaveolens, $C$. citratus, ranging between 1.88 and 2.09 and the untreated control $(3.18 \mathrm{~g})$. The highest value $(6.07 \%)$ and the lowest value $(3.75 \%)$ of mean

percentage loss of cowpea seeds were recorded in the untreated control and $A$. indica leaf powder respectively. Also, there was no significant $(p>0.05)$ difference in mean percentage 
weight loss of cowpea seeds treated with the leaf powders of $A$. indica, $P$. guineense, $H$. suaveolens, C. citratus and the untreated control.

\section{DISCUSSION}

The literature shows that plant powders have insecticidal action against $C$. maculatus and other stored product insect pests (Adedire and Lajide,, 1999; Asawalam and Emosairue, 2006; Musa and Uddin II, 2016). Also, in a previous study, Oparaeke et al., (2002) reported that cowpea seeds treated with Ocimum gratissimum and $H$. suaveolen caused reduction in progeny development of $C$. maculatus.

The results of this study agree with the findings of Idoko and Adesina (2012) who reported that $P$. guineense caused the mortality of $C$. maculatus adults and eventual suppression of progeny emergence due to contact toxicity of the powder. Previous investigation showed that mortality of C. maculatus increased with increase in the rate of plant part powder applied with higher rate assumed to be having higher active ingredients against the insect (Musa, 2012).

The adult mortality recorded might be attributed to the leaf powders that may have caused abrasion of the insect cuticle. The increasing order of effectiveness of the botanicals in terms of their insecticidal activities against $C$. maculatus was $P$. guineense, $C$. citratus, $H$. suaveolens, and $A$. indica. The insecticidal properties of $A$. indica and $P$. guineense could be attributed to the presence of azadirachtin and piperine respectively (Oparaeke, 2006).

Hyptis suaveolens offered the better protection against the number of emerged adults of $C$. maculatus because it was consistently significantly better than the untreated control during the study period. Reduction in the number of emerged adults may be associated with possible ovicidal and larvicidal activities of the botanicals. In this study, A. indica had the lowest emergence of $C$. maculatus adults. The reduced adult emergence in all the plant powders may also be due to mortality of the adult beetle before oviposition. It could also be that the plant materials made the male sterile; thus made the females produced non-fertile eggs (Ojianwuna and Umoru, 2010). Among the plant powders, $H$. suaveolens conferred better protection of cowpea seeds through prevention of emergence during the study period. Generally, adult emergence increased with increase in exposure period despite the presence of the plant powders.

\section{CONCLUSION}

This study shows that the leaf powders afforded varying degrees of cowpea seed protection against bean beetle, C. maculatus under small scale storage. However, A. indica and $H$. suaveolens leaf powders offered better protection than $P$. guineense and $C$. citratus and are 
therefore recommended for further empirical investigation to be able to incorporate them into much desired preservation of bulk commodities.

Table 1: Mean percentage mortality of Callosobruchus maculatus adults on cowpea seeds treated with the same rate of different leaf powders

\begin{tabular}{lcccc}
\hline Plant Powder & \multicolumn{4}{c}{ Days after treatments (DAT) } \\
\cline { 2 - 5 } & $\mathbf{1}$ & $\mathbf{2}$ & $\mathbf{3}$ & $\mathbf{4}$ \\
\hline A. indica & $0.0_{\mathrm{b}}(0)$ & $0.0_{\mathrm{b}}(0)$ & $30.0_{\mathrm{a}}(100)$ & $30.0_{\mathrm{a}}(100)$ \\
P. guineense & $0.0_{\mathrm{b}}(0)$ & $6.0_{\mathrm{b}}(20)$ & $6.0_{\mathrm{c}}(20)$ & $18.0_{\mathrm{b}}(60)$ \\
H. suaveolens & $6.0_{\mathrm{a}}(20)$ & $12.0_{\mathrm{a}}(40)$ & $18.0_{\mathrm{b}}(60)$ & $30.0_{\mathrm{a}}(100)$ \\
C. citratus & $6.0_{\mathrm{a}}(20)$ & $6.0_{\mathrm{b}}(20)$ & $18.0_{\mathrm{b}}(60)$ & $18.0_{\mathrm{b}}(60)$ \\
Control & $0.0_{\mathrm{b}}(0)$ & $0.0_{\mathrm{b}}(0)$ & $0.0_{\mathrm{d}}(0)$ & $0.0_{\mathrm{d}}(0)$ \\
SE \pm & 0.21 & 0.97 & 0.53 & 2.30 \\
\hline LSD $_{(0.05)}$ & $\mathbf{0 . 7 3}$ & $\mathbf{3 . 3 6}$ & $\mathbf{1 . 8 4}$ & $\mathbf{8 . 0 4}$ \\
\hline
\end{tabular}

Values in the same column followed by common subscript do not differ significantly different at $p$ $=0.05$ using Least Significant Difference. Values in parentheses represent percentage mortality.

Table 2: Emergence of Callosobruchus maculatus adults on cowpea seeds treated with the same rate of different plant leaf powders

\begin{tabular}{|c|c|c|c|c|c|c|c|}
\hline \multirow[t]{3}{*}{ Plant Powder } & \multicolumn{7}{|c|}{ Progeny emergence of C. maculatus (DAT) } \\
\hline & \multirow[t]{2}{*}{29} & \multicolumn{2}{|c|}{30} & 31 & \multicolumn{2}{|c|}{32} & \multirow[t]{2}{*}{33} \\
\hline & & & & & 35 & & \\
\hline A. indica & $5.0_{b}$ & $1.0_{b}$ & $1.00_{d}$ & $1.33_{\mathrm{c}}$ & $8.00_{a b}$ & $18.3_{d}$ & $21.33_{b}$ \\
\hline$P$. guineense & $6.0_{b}$ & $3.33 \mathrm{ab}$ & $3.33_{b}$ & $7.00_{b}$ & $7.67 \mathrm{ab}$ & $27.00_{b}$ & $70.00 \mathrm{a}$ \\
\hline H.suaveolens & $0.0_{c}$ & $0.00_{b}$ & $0.00_{d}$ & $0.67_{c}$ & $1.00 \mathrm{~b}$ & $10.33_{c}$ & $21.67 \mathrm{~b}$ \\
\hline C. citratus & $0.0_{c}$ & $0.00_{b}$ & $1.33_{c}$ & $2.00_{c}$ & $16.33 a$ & $18.67_{d}$ & $34.00_{a b}$ \\
\hline Control & $10.33_{a}$ & $10.33 \mathrm{a}$ & $11.0_{a}$ & $13.00 \mathrm{a}$ & $18.33 \mathrm{a}$ & $48.00 \mathrm{a}$ & $70.00 \mathrm{a}$ \\
\hline SE \pm & 0.30 & 2.55 & 0.33 & 1.59 & 3.35 & 1.11 & 12.36 \\
\hline $\operatorname{LSD}_{(0.05)}$ & 1.04 & 8.86 & 1.15 & 5.53 & 11.65 & 3.86 & 42.99 \\
\hline
\end{tabular}

Values in the same column followed by common subscript(s) do not differ significantly different at $p=0.05$ using Least Significant Difference. $\quad$ DAT $=$ Days after treatments $S E=$ Standard error 
Table 3: Effects of different plant powders on cowpea seed damage

\begin{tabular}{lcccc}
\hline Plant Powder & \multicolumn{4}{c}{ 39 DAT } \\
\cline { 2 - 5 } & $\begin{array}{c}\text { Rate } \\
(\mathrm{g})\end{array}$ & $\begin{array}{c}\text { Wt. of } \\
\text { damaged } \\
\text { seeds }(\mathrm{g})\end{array}$ & $\begin{array}{c}\text { Wt. of } \\
\text { undamaged } \\
\text { seeds }(\mathrm{g})\end{array}$ & Total weight $(\mathrm{g})$ \\
\hline A. indica & 2.5 & $1.57 \pm 0.89$ & $46.55 \pm 1.01$ & $48.12 \pm 0.14$ \\
P. guineense & 2.5 & $4.02 \pm 3.90$ & $43.95 \pm 4.45$ & $47.97 \pm 0.55$ \\
H. suaveolens & 2.5 & $1.87 \pm 0.77$ & $46.16 \pm 0.92$ & $48.04 \pm 0.21$ \\
C. citratus & 2.5 & $1.83 \pm 0.46$ & $46.31 \pm 0.60$ & $48.11 \pm 0.13$ \\
Control & 0.0 & $0.56 \pm 0.40$ & $46.41 \pm 0.82$ & $46.97 \pm 1.07$ \\
\hline LSD $_{(0.05)}$ & & NS & NS & NS \\
\hline NS: Not Signifcant & \multicolumn{5}{c}{}
\end{tabular}

NS: Not Significant

Table 4: Effects of different plant powders on the weight loss of cowpea seeds

\begin{tabular}{lcc}
\hline Plant Powder & Mean Wt. loss $\mathbf{( g )}$ & Wt. loss (\%) \\
\hline A. indica & $1.88 \pm 0.14$ & $3.75 \pm 0.28$ \\
P. guineense & $2.09 \pm 0.61$ & $4.06 \pm 1.10$ \\
H. suaveolens & $1.96 \pm 0.21$ & $3.87 \pm 0.25$ \\
C. citratus & $1.88 \pm 0.13$ & $3.77 \pm 0.25$ \\
Control & $3.18 \pm 1.22$ & $6.07 \pm 2.13$ \\
\hline LSD $_{(0.05)}$ & NS & NS \\
\hline
\end{tabular}

NS: Not Significant 


\section{REFERENCES}

Adedire, C.O. (2008). Biology, economy and control of insect pest of stored cereal grains. In: Ofuya T. I. and Lale N.E.S, (Ed). Pests of Nigeria, Ecology and Control. Dave Collins Publication Nigeria 59-94.

Adedire, C.O. and Lajide, L. (1999). Toxicity and oviposition deterrence of some plant extracts on cowpea storage bruchid, Callosobruchus maculatus Fabricius Journal of Plant Diseases and Protection 106: 647-653.

Akinkurolere, R.O., Adedire, C.O., and Odeyemi, O.O. (2006). Laboratory evaluation of the toxic properties of forest Anchomanes, Anchomanes difformis against pulse beetles Callosobruchus nmaculatus (Coleoptera: Bruchidae). Insect Science. 13:25-29.

Aliyu, T.H., Balogun, O.S., and Adeoti, O.M. (2011). Pathogenic responses of cowpea (Vigna unguiculata) inoculated with cucumber mosaic virus to soil amendment with neem leaf powder. Agrosearch. 11(1): 99-110.

Asante, S. K., Tamo, M., and Jackai, L.E.N. (2001). Integrated management of cowpea insect pests using elite cultivars, date of planting and minimum insecticide application. African Crop Science Journal. 9(4): 655-665.

Asawalam, E.F. and Emosairue, S.O. (2006). Comparative efficacy of Piper guineense (Schum and Thonn) powder and pirimiphos-methyl dust against Sitophilus zeamais (Coleoptera: Cuculionidae) in stored maize. Nigerian Journal of Entomology 23: 30-33.

Dike, M.C., and Mbah, O.O. (1992). Evaluation of lemon grass (Cymbopogon citratus Staph.) products in the control of Callosobruchus maculatus Fab. (Coleoptera: Bruchidae) on stored cowpea. Nigerian Journal of Plant Protection. 14: 88-91.

Idoko, J.E. and Adesina, J.M. (2012). Infestation level of Callosobruchus maculatus of cowpea using different particle sizes of Eugenia aromatic and Piper guineense powders. World Journal of Engineers and Pure and Applied Sciences 2(5): 156-160. 
Ivbijaro, M.F. (1989). The efficacy of seed oils of Azadirachta indica A. Juss against Callosobruchus maculatus (F.). Insect Science and its Application 11(2): 149-152.

Kwaifa, N.M., Ibbrahim, N.D., Dike, M. C., and Abubakar, M.G. (2012). Bioefficacy of neem and mahogany extracts for control of cowpea flower thrips, Megalurothrips sjostedti Trybom (Thysanoptera: Thripidae) and grasshopper, Ailopus simulatrix Walker (Orthoptera: Pyrgomorphidae) in Sudan Savanna, Nigeria. Nigerian Journal of Entomology 29: 3142.

Lanyintuo, A.S., Lowenberg-DeBoer, J., Faye, M., Lambert, D., Ibro, G., Moussa, B., Kergna, A., Kushwaha, S., Musa, S., and Ntoukam, G. (2003). Cowpea Supply and Demand in West Africa. Field Crops Research 82: 215-231.

Lale, N.E.S. (2002). Stored product entomology and acarology in tropical Africa, Mole publication, Maiduguri, Nigeria. 204pp.

Lale, N.E.S. (2006). Dictionary of entomology and acarology. Mole Publication Nigeria Limited, Port Harcourt, Nigeria. 265 pp.

Musa, A.K. (2007). Control of Callosobruchus maculatus (F.) (Coleoptera: Bruchidae) in stored cowpea with Piper guineense Schum. \& Thonn. Journal of Tropical Biosciences 7: 2023.

Musa, A.K. (2008). Laboratory evaluation of the toxicity of methanolic extract of African bush tea seed (Hyptis suaveolens Poit.) for the control of cowpea beetle (Callosobruchus maculatus Fabricius). Agro-Science 7(2): 114-117.

Musa, A. K. (2012). Suppression of seed beetle, Callosobruchus maculatus population with root bark powder of Zanthoxylum zanthoxyloides (Lam.) Waterm. (Rutaceae) on cowpea (Vigna unguiculata (L.) Walp.) Agrosearch 12(2): 196-204.

Musa, A. K. (2013). Protection of groundnut (Arachis hypogaea L.) against Trogoderma granarium Everts (Coleoptera: Dermestidae) using African bush tea (Hyptis suaveolens 
Poit.) in the southern Guinea Savanna of Nigeria. Global Journal of Biology, Agricultural \& Health Sciences 2(3): 226-228.

Musa, A.K. and Lawal, M.T. (2016). Insecticidal activity of Citrus sinensis (L.) and Parkia biglobosa (Jacq.) extracts against Trogoderma granarium Everts. Agriculture \& Forestry 62(3): 197-206.

Musa, A.K. and Uddin II, R.O. (2016). Insecticidal Potential of indigenous plant powders against beetle, Callosobruchus maculatus (F.)(Coleoptera: Chrysomelidae) in stored cowpea. International Journal of Phytofuels and Allied Sciences (A Journal of the Society for the Conservation of Phytofuels) 5(1): 1-14.

Ofuya, T.I. (2003). Biology, ecology and control of insect pest of stored legumes in Nigeria. In: Pests of stored cereals and pulses in Nigeria: Biology, ecology and control. Edited by T.I Ofuya, N.E.S. Lale, Dave Collins Publication Nigeria, 24-58.

Ojianwuna, C. and Umoru, P.A. (2010). Effects of Cymbopogon citratus (lemon grass) and Ocimum suave (wild basil) applied as mixed and individual powders on the eggs laid and emergence of adult Callosobruchus maculatus (cowpea bruchids). African Journal of Agricultural Research 5(20): 2837-2840.

Oparaeke, A.M., (2006). Field evaluation of extracts of five Nigerian spices for control of postflowering insect pests of cowpea, Vigna unguiculata (L.) Walp. Plant Protection Science 41(1): 14-20.

Opoaraeke, A.M., Dike, M.C. and Amatobi, C.I. (2002). Preliminary investigation of clove, Syzygium aromaticum (L.) Merr. and Perr. as a source of valuable insecticide for field pest control on cowpea. Nigerian Journal of Agricultural Extension 13: 178-181.

Rahman, A. and Talukder, F.A. (2006). Bioefficacy of some plant derivatives that protect grains against the pulse beetle, Callosobruchus maculatus (F). Journal of Insect Science 6(3): 1-10. . 
Singh, B., Ajeigbe, H.A., Tarawali, S.A., Femandez-Rivera, S., and Abubakar, M. (2003). Improving the production and utilization cowpea as food and fodder. Field Crops Research. 84: 150-169

Uddin II, R.O. and Sanusi, S.A. (2013). Efficacy of olive oil, groundnut oil, soybean oil and palm kernel oil in the control of Callosobruchus maculatus (F.) in stored cowpea (Vigna unguiculata L. Walp). Agrosearch 13(2): 67-72.

Udo, I.O. and Harry, G.I, (2013). Effect of groundnut oil in protecting stored cowpea; Vigna unguiculata from attack by cowpea weevil, Callosobruchus maculatus. Journal of Biology, Agriculture and Health Care. 3(1):89-92. 